\title{
International Constraints and Electoral Decisions: Does the Room to Maneuver Attenuate Economic Voting?
}

\author{
Running Header: International Constraints and Electoral Decisions
}

Keywords: Economic Voting; International Constraints; Room to Maneuver; Survey Experiment, Economic Crisis

\author{
Spyros Kosmidis \\ University of Oxford \\ Department of Politics and International Relations \\ Manor Road Building \\ Manor Road \\ Oxford, UK \\ spyros.kosmidis@politics.ox.ac.uk
}

This research benefited from the generous funding provided by the John Fell Fund at the University of Oxford (Project Ref: 122/685). The author would like to thank lannis Konstantinidis for supervising data collection, Elias Dinas, David Rueda, Catherine de Vries, Tim Hellwig, Ray Duch, Mark Kayser, Zach Greene, Rob Johns, Ben Ansell, Kristian Gleditsch, the editor of the AJPS and three anonymous reviewers for useful comments and advice. As always, any errors in the manuscript are the author's sole responsibility. 


\title{
International Constraints and Electoral Decisions: Does the Room to Maneuver Attenuate Economic Voting?
}

\begin{abstract}
Prominent studies of electoral accountability and economic voting suggest that government constraints and international financial structures decrease the economic vote. The proposed mechanism is often labelled as the Room to Maneuver and it posits that because elected officials have limited space to propose and implement economic policy, politicians can shirk responsibility, and thus voters are less likely to place voting weights on the economy. However, results from elections that took place in Europe during the Great Recession and scholarly research on economic voting in these elections cast serious doubts on the causal mechanism. This paper directly tests this mechanism with a survey experiment using data from Greece (the country most affected by the debt crisis). The results suggest that, although the economic vote is strong and substantive, its size does not vary across the Room to Maneuver treatments. This finding informs the literature on economic voting and carries out important implications for party strategies with respect to exogenous policy impositions and their electoral effects.
\end{abstract}

Keywords: Economic Voting; International Constraints; Room to Maneuver; Survey Experiment

Replication Materials: The data, code and any additional materials required to replicate all analyses in this article are available on the American Journal of Political Science Dataverse within the Harvard Dataverse Network, at: doi:10.7910/DVN/K70CDX

WordCount: 8812 


\section{Introduction}

We know that economic conditions determine election outcomes (for instance Tucker et al., 2006; Lewis-Beck and Stegmaier, 2008, 2013), yet much of this empirical regularity has been distorted by a number of conditions that cause fluctuations in the economic vote (see, e.g. Powell and Whitten, 1993; Hobolt, Tilley and Banducci, 2013; Kayser and Peress, 2012; Anderson, 2006; Duch and Stevenson, 2008). One prominent condition relates to globalization and the international constraints posed to national governments (for a review see Vowles and Xezonakis, 2016). According to this view, international economic forces offer leeway to politicians to shirk responsibility for policy outcomes by signaling that they have limited room to maneuver economic policy (Hellwig, 2001; Hellwig and Samuels, 2007; Hellwig, 2008, 2015; Duch and Stevenson, 2010, 2008).

This pattern has serious implications for electoral democracy and our understanding of the linkages between electors and politicians. Indeed, work on party competition and representation suggests that economic interdependence distorts the strategic incentives of parties (Ward, Ezrow and Dorussen, 2011) and makes their policy pledges less responsive to public opinion (Ezrow and Hellwig, 2014). Moreover, mass publics tend to demand less from governments when they perceive them as constrained by the liberalization of the markets (Hellwig, 2014). These findings, coupled with the results on the limiting role of globalization for economic voting, sketch a very pessimistic view of democratic politics (Hellwig, 2001; Hellwig and Samuels, 2007; Hellwig, 2008; Duch and Stevenson, 2010, 2008; Hellwig, 2015). Across these literatures, the chief conditional underpinning relates to how much room governments have to design and implement policy. With only few exceptions (see e.g. Vowles, 2008), the Room to Maneuver thesis has found extensive support using individual and aggregate data from several democracies across Europe and it is considered one of the key reasons why the economic vote fluctuates. However, the exact theoretical causal mechanism has not been put to an experimental test. 
These experimental tests are warranted for a number of reasons. First, most individual-level assessments use observational data to measure the assignments of responsibility that are susceptible to voter rationalization. Second, because these measures are susceptible to rationalization, the statistical findings from these studies tend to produce unreliable empirical results. By randomly assigning respondents to different responsibility treatments these problems are largely addressed. Finally, and before anything, although the observational work on the topic has found extensive support for the Room to Maneuver thesis, electoral outcomes during the Great Recession in democracies with only limited room to design and implement economic policy cast doubts on the applicability of the theory.

A series of works has highlighted the importance of economics in these elections. Bartels (2011) demonstrates using comparative data that the economy is the key determinant of incumbent vote losses. The same pattern has been replicated across a wide range of single country case studies. Lobo and Lewis-Beck (2012) and Magalhães (2014), for example, found extensive economic voting in Portugal, Marsh and Mikhaylov (2012) confirmed the pattern for Ireland, while extensive economic voting was reported using Greek data (Nezi, 2012; Kosmidis, 2014). In Spain, Fraile and Lewis-Beck (2014) concluded that economic voting was also strong despite the significant shift in the assignment of responsibility for economic outcomes (see FernándezAlbertos, Kuo and Balcells, 2013). The overall pattern is one in which the economic vote is on the rise after the economic crisis (Lewis-Beck and Costa-Lobo, 2016). Crucially, it seems that economic salience across affected countries has also increased when comparing pre and post crisis survey responses (Singer, 2013).

This paper seeks to test the micro mechanism of maneuverability by analyzing an original survey experiment in Greece. Although the evidence from crisis-laden democracies is not a direct refutation of the theory, it encourages a reassessment of the causal mechanism. ${ }^{1}$ The

\footnotetext{
${ }^{1}$ The proper test would be one where economic voting is analyzed in countries that have similar economic conditions but with sufficient room to maneuver the economy.
} 
Greek case is one that can shed light on the nexus between Manoeuvrability, Responsibility and Accountability as the elected governments during the Great Recession had minuscule space to design their preferred economic policy. The survey experiment is designed to randomly assign voters to different scenarios and it was fielded at a point when the imposed program was just about to end, allowing the effective manipulation of perceptions of responsibility over future outcomes. Voters, according to the results, select the political actors that can maximize their utilities and resolve their economic discontent without considering the amount of leverage they have to design and implement policy. In short, the room to maneuver does not influence economic voting and this carries important implications; politicians seeking to escape the blame for poor economic performance are condemned to be unsuccessful in bad economic times.

\section{International Constraints \& Economic Voting}

In the most recent review of economic voting studies, Lewis-Beck and Stegmaier (2013) reaffirmed the predominance of economic explanations of the vote. The mechanism suggests that improvements in the economy bring about increases in incumbent party support, whereas economic declines are associated with linear losses in government popularity. This is the case because either incumbent politicians are held to account for economic outcomes or, equally, because voters select good or bad politicians and their economic anticipations mark their political choices (Fearon, 1999). In both paradigms, the empirical observation is mostly similar and it is susceptible to important contextual conditionalities (for a good overview see Lewis-Beck, 1988; Lewis-Beck and Paldam, 2000; Lewis-Beck and Stegmaier, 2000). The size of these popularity gains or losses are conditional on whether there is clarity or ambiguity in the assignment of responsibility over economic policy (Powell and Whitten, 1993; Anderson, 1995, 2000; Hobolt, Tilley and Banducci, 2013). A typical example of such contextual conditions is multi-level governance and supranational institutions. Hobolt, Tilley and Wittrock (2013), for example, have found that voters 
find it hard to assign responsibility because of the varying levels of information (see also Johns, 2011). As such, the collective voting weights placed on the economy will vary substantially across different levels of exposure and integration to international structures like the European Union.

The above pattern has implications for economic voting. Studies examining the role of globalization in mass political behavior suggest that economic interdependence and non-elected actors have further complicated the assignment of government responsibility for economic outcomes (Hellwig and Samuels, 2007). Accordingly, globalization and domestic electoral politics are closely linked because economic interdependence influences the ability of domestic actors to design and implement policy. If countries are indeed economically interdependent and there is little room to maneuver the economy, then the blurred lines of responsibility should lower the economic vote. Reversely, in a closed economy where the incumbent government has full responsibility over economic outcomes, voters should place considerable voting weights on economic considerations. The statistical evidence is in full support of the empirical relationship (e.g. Hellwig, 2001; Hellwig and Samuels, 2007; Hellwig, 2008, 2015).

Duch and Stevenson (2010) have proposed a similar mechanism to link international constraints and economic voting that makes similar predictions about economic voting (see also Duch and Stevenson, 2008, Ch5). They elaborate on works in public economics whereby voters distinguish between exogenous (i.e. globalization) and competency (i.e. domestic) signals (Alesina, Londregan and Rosenthal, 1993). The key idea is that economic outcomes due to politically motivated domestic shocks (policy outcomes produced by the elected governments) are ill-equipped to provide information to voters if not considered in tandem with exogenous shocks. Voters, according to this scheme, tend to distinguish between international and national causes of economic change and evaluate the relative strength of each component (national and international). In effect, economic voting increases when national competency signals are stronger compared to the respective international signals.

Kayser and Peress (2012) proposed a different mechanism. According to their benchmarking 
model, vote choices on the basis of the economy hinge on comparisons. Building on works on both economics and social psychology, they theorize that electors engage in comparisons of economic performance across countries. As a consequence,... the larger international component of an open economy leads to smaller deviations from it and, hence, a weaker economic vote. (Kayser and Peress, 2012, p.664). In a recent extension of their research, they actually found that forces of globalization synchronize the national business cycles and thus voters in open economies observe smaller deviations in the economic performance of governments (Kayser and Peress, 2016). In their view, this is what causes the attenuation in economic voting, not economic interdependence and the little room to maneuver the economy.

Indeed, a number of researchers have suggested that economic integration (the obstacle to retain the Room to Maneuver) leaves national governments with sufficient leverage to implement policy. According to the literature, increases in government expenditure is positively correlated with globalization (Garrett, 1998a,b; Mosley, 2000; Garrett and Mitchell, 2001). ${ }^{2}$ Although this conclusion has been contested (e.g. Rodrik, 1997), it appears that popularly elected governments can still implement policy of their liking. ${ }^{3}$ To be sure, what really matters in this case is how politicians use rhetoric to escape blame and how voters perceive globalization with respect to maneuvrability. Although citizens assign some blame to non-elected actors (Alcañiz and Hellwig, 2011) and globalization reduces the amount of responsibility assigned to domestic ones (Hellwig, 2015), when it comes to perceptions of policy leverage the evidence suggests that electors in open economies don't perceive their governments as more constrained. Vowles (2008), for example, has found that there was no difference in perceptions of maneuvrability between closed and open economies using data from over 40 democracies. Hellwig, Ringsmuth and Freeman (2008) using experimental data from the US found that only a few educated partisans were able to assign blame

\footnotetext{
${ }^{2}$ Burgoon (2001) suggests that the effect is not uniform across different sectors of the welfare state.

${ }^{3}$ The general assumption is that government spending is evidence of Room to Maneuver, yet, clearly, this is a strong assumption to make. Policy freedom can also be evaluated on the basis of trade and labor agreements.
} 
to international actors. Fernández-Albertos, Kuo and Balcells (2013) found important partisan asymmetries in blaming non-elected actors in Spain, yet these differences appear to cancel out in the full sample. Similarly, Hellwig and Coffey (2011) found that partisan preferences in the UK color perceptions of responsibility during the 2008 crisis strengthening the view that past individual-level results on the topic are prone to voter rationalization.

\section{Empirical Inconsistencies}

After the collapse of the Lehmann brothers and the official beginning of the global economic crisis, many countries on the European periphery experienced severe economic declines. Because of high debt and high interest rates they were unable to borrow money from the markets to pay salaries or/and balance their budgets. They thus signed conditional loan agreements with international actors like the European Central Bank (ECB) and the IMF.

Whereas the actual political leverage governments have is an open empirical debate, it is widely accepted that the policy impositions by the International Monetary Fund (IMF) and the European Union (EU) during the Great Recession severely reduced the Room to Maneuver. Even in past interventions, the conditions attached to the loans were often so strict that newly elected governments would reply positively to the 'letter of intent", just to use the Fund as a scapegoat for corrective macroeconomic measures (Dreher and Vaubel, 2004; Vaubel and Willett, 1991). Although the Fund became a crisis management association with a revamped rhetoric, both the content and the strict loan-conditionality remained unchanged (for a summary see Kentikelenis, Stubbs and King, forthcoming). Theories that consider the room to maneuver as the causal underpinning of the attenuation of the economic vote in economically interdependent democracies would have anticipated lower economic voting in the European periphery. Elections that took place during and after the EU bailouts, however, produced results that are at odds with the established mechanism linking globalization and economic voting.

In Greece, research shows that the economy was the single most important consideration for 
voters. For example, Nezi (2012) found strong asymmetrical effects of the economy for Greek voters while Teperoglou and Tsatsanis (2014) clearly attributed the collapse of the mainstream parties to economics (see also Kosmidis, 2014). A casual inspection of economic voting at the macro level can illuminate the changing patterns of accountability before and during the crisis. Time series models of economic voting before and during the IMF interventions reveal that the size of the economic vote increased (see Figures A.1 \& A.2 the Online Appendix). The clear increase in economic voting encourages a re-assessment of the causal relationship at micro level.

\section{Research Design \& Estimation}

The research design assumes that voters are rational and vote on the basis of their expected utilities. Each political party competing in the election has a particular competence level and voters always select the party that is able to deliver the most desirable national economic outcomes (Fearon, 1999). To reach to that decision voters consult their future expectations about national economics. If they think that the governing party will deliver better outcomes in the foreseeable future then they vote for the incumbent. If not, they choose one of the other competing parties. It is also assumed that this mechanism is conditional upon how much room the national government will have to implement economic policy. This is the condition to be manipulated. According to the aforementioned theories we expect higher economic voting when there is more room to manipulate the economy and less economic voting when there is little or none.

\section{External Validity, Manipulations \& Measures}

As it was mentioned in previous sections, bail-out agreements came along with imposed measures from the International Monetary Fund, the European Central Bank and the European Union. These loan instalments would be made available on the basis of the agreed policies and the schedule proposed by the IMF (in collaboration with the government)(for details see EU, 2015). 
Part of the agreement was that the IMF team overlooking the progress of the 'reforms' would leave Greece by the end of 2014 and that from that point on Greek governments would have leverage to design and implement policy. As the fifth and final review of the second Bailout Programme implied, "With only $€ 1.9$ billion remaining in committed financing from European partners following the completion of the current review, the authorities have mobilized alternative resources to meet prospective gross financing needs...": (IMF, 2014, p.21). ${ }^{4}$ Portugal, for example, that experienced similar impositions from the same group of institutions, decided not to sign the letter of intent for additional support as interest rates from the financial markets were sufficiently low to borrow money. Greece had a very similar strategy and, indeed, some months before fieldwork the coalition government attempted to borrow outside of the bailout agreement (i.e. from the financial markets). The government considered this a signal that they could make it without a bail-out agreement, but the interest rates were not as low as those offered by the lenders. $^{5}$

Experimentation with the Room to Maneuver would have been completely redundant in the first years of the bailout because the elected government had no leverage to deliver their electoral mandate. With the program coming to an end, an excellent opportunity appeared to successfully manipulate the levels of maneuverability and see how they influence economic evaluations and vote choices. In fact, around the dates of the fieldwork, a series of articles appeared in prominent international outlets that discussed the possibility of an early exit of the IMF team from Greece before the agreed date. This possibility was ever more plausible considering the fact that the

\footnotetext{
${ }^{4}$ It was later decided that the IMF would leave in the beginning of 2015. However, the discussions were stopped once a new government took office in late January 2015. Since then, Greece has signed a third bail-out agreement with the lenders.

${ }^{5}$ When the program ended in December 2014, the government requested a two month postponement of the program. This was a tactical move, and in January 2015 a national election took place and the major opposition party, SYRIZA, won by a landslide.
} 
goal of a primary budget surplus was achieved some months before the survey was fielded (IMF, 2014, p.2). Several editorials (Danhong, 2014; Kontogiannis, 2014) right before fieldwork, but also some soon after the surveys were conducted (see e.g. Smith, 2014) describe the decisions facing the Greek government and the consequences of ending the bailout agreement. ${ }^{6}$

In terms of the chief aim of the study the expectations are straight-forward. If electable political actors are mostly responsible for economic policy, then economic voting should be on the rise. If voters extract signals to indicate that the national actors could have done little to influence economic outcomes, then economic voting should be significantly lower. To test this mechanism this study relies on a simple experiment that took place in Greece in June 2014. The experiment was conducted on a representative sample $(\mathrm{N} \simeq 1100)$ of the Greek population. The interviews were conducted using computer-assisted telephone interviews (CATI) by 16 interviewers and two supervisors at the Public Opinion and Market Research Unit of the University of Macedonia. ${ }^{7}$ The translated question wording and the actual manipulations can be found in Table 1. The response categories for prospective economic evaluations were Improve a lot, Improve, Stay the same, Deteriorate, Deteriorate a lot, DK/DA. After reporting their economic evaluations, respondents were asked to report how they would vote if there was a general election and the question was phrased to temporally align the economic assessment with vote intentions: Considering the General Election at the end of the current parliament, how would you vote? ${ }^{8}$

\footnotetext{
${ }^{6}$ Note that only articles written in English are mentioned here. Naturally, this discussion featured prominently in the Greek media.

${ }^{7}$ www. uom.edu.gr

${ }^{8}$ The response categories were the following:

PASOK, New Democracy, KKE, LAOS, Syriza, DIMAR, POTAMI, INDEPENDENT GREEKS, Other Party, Undecided, Will not vote, Didn't Answer. In Greece, Parliament runs for 4-year terms and the last election was in June 2012. In other words, the economic evaluation and the voting intention items are temporally aligned.
} 
Although the consequences of using prospective rather than retrospective measures are limited for the size of the economic vote (see Hellwig, 2008; Singer and Carlin, 2013), the choice to manipulate economic prospects warrants attention as the Room to Maneuver theory (and much of the economic voting literature) is based on retrospective assessments of the economy. To be sure, many of the individual-level observational works on the Room to Maneuver clearly show that there is no difference in the main finding when analyzed with future oriented measures of economic assessment (Hellwig, 2008). ${ }^{9}$ The decision to use prospects is guided by three key factors; retrospective economic evaluations exhibit minimal variation when measured in times of crisis and often lead to null results when predicting the vote. Secondly, recent research that examines endogeneity in economic perceptions (see for e.g. Wilcox and Wlezien, 1993) suggests that in times of crisis economic prospects are less endogenous (see Chzhen, Evans and Pickup, 2014). Finally, in the context of experimental research in general, and this experiment in particular, it is much easier and theoretically plausible to manipulate economic anticipation. As shown in Table 1 the survey items give a specific temporal horizon of two to three years that corresponds to the end of the parliamentary term when the survey was fielded. This way there is enough time for economic policy to have tangible effects but it also allows respondents to infer who the incumbent is without this being explicitly mentioned in the item. ${ }^{10}$

\footnotetext{
More information on the role, the strength and the ideology of the main competing parties can be found in the Online Appendix in Table A.5.

${ }^{9}$ In fact, Hellwig, in his analyses of French elections, used only prospective evaluations and for the British case he compared them to retrospective ones. There were no substantial differences between forward-looking and past-oriented evaluations.

${ }^{10}$ This is also linked to the endogeneity that plagues economic evaluations. Although respondents need to know who will be in office (for the argument see Michelitch et al., 2012), mentioning the coalition partners in the question would increase the likelihood of voter rationalization.
} 
The validity of the experimental design is conditional on the independence of the economic evaluation from participation in one of the two treatments. It is very likely that upon receiving the treatment, different sub-groups of the sample would form different economic evaluations depending on whether they received $\tau_{1}$ or $\tau_{2}$. For example, with the IMF out and thus with full room to implement policy, voters with negative stances toward the IMF or the government could become optimistic because a better economic programme might arise that suits their preferences. If, on the other hand, the IMF stays and people thought that the economy generally benefited from the imposed policy mixture, then optimism could have a completely different meaning. This can have serious implications for measuring economic voting conditional on the treatments. One way to examine this possibility is to 1) see whether economic evaluations vary by treatment and 2) whether different subgroups in the sample respond differently to the treatment when they report their economic evaluation. With regard to the former, economic evaluations show considerable variation with $32 \%(7.34 \%+25.19 \%)$ of the sample being optimistic, $45 \%(28.16 \%+16 \%)$ being pessimistic and $21 \%$ reporting that the national economy will remain stable, but these margins do not vary substantially across the control and the two treatment groups. Regarding subgroup treatment heterogeneity, Figure 1 shows that the possibility of endogenous treatment effects can be discarded.

\section{-Figure 1-}

Figure 1 plots the difference across $\tau_{1}$ and $\tau_{2}$ in economic optimism conditional upon voter characteristics. The key variables from this list is the EUVoteOpp/EUVoteGov and the VotelntentionOpp/VotelntentionGov covariates that correspond to vote recall from the European Parliament election that took place some weeks before fieldwork and the variable measuring vote intentions. Across the covariates the mean differences are very close to zero and in all cases it is included in the confidence intervals. 


\section{Manipulation Check}

Although maneuverability has no substantive effect on economic assessments, it is important to see whether the experimental manipulation was successful (i.e. manipulation check). To test this, the original survey included a measure of responsibility that came exactly after the vote intention question. The question was phrased in the following way: Who do you think will be responsible for the economy in the coming years?. The respondents were prompted to answer the question on a 0-10 scale where 0 denotes responsibility for economic outcomes to the lenders and 10 denotes responsibility to the national government. The differences across the groups are reported in Table 2.

As is clear from Column 1 on Table 2, the Full Room treatment was successful and appears to be statistically different from the control group toward the direction of national responsibility. In other words, whatever change, if any, in our estimate of the economic vote can be attributed to participation of the group that assumes national responsibility for the economy. As Column 2 in Table 2 suggests, the treatment effect is robust to the inclusion of both demographic and political (i.e. party preference) covariates. Unsurprisingly, the No Room treatment is not statistically different from the control group. This has to do with the fact that it merely describes and thus only primes the real situation between the lenders and the national government. ${ }^{11}$ Clearly, if the studies focusing on retaining the room to maneuver are correct and there is a conditional effect, then the Full Room treatment should increase the size of the economic vote.

-Table 2-

\footnotetext{
${ }^{11}$ Although it is not statistically different from the control group, the No Room treatment serves an important purpose. The two experimental manipulations might induce additional considerations to the subjects (in this case an increase in the salience of the economy). By doing so, there might also be an increase in the economic vote that should not be attributed to the original purpose of the treatment (i.e. shifting responsibility). Because this is the case for both treatments, the No room manipulation can serve as an alternative benchmark for the Full Room treatment.
} 


\section{Results}

Before moving to the empirical estimation of the experiment, the unconditional effect of economic prospections on the vote (that is assuming a zero conditional effect) would be informative. To calculate the predictions, the dependent variable was coded so that (1) corresponds to New Democracy and PASOK (the parties of the governing coalition during fieldwork) and (0) to all other parties. As expected, the economic vote for the full sample of observations is strong, significant and substantial. A standard deviation change (1.33) would produce a $16 \%$ (0.167, $95 \% \mathrm{Cls}[0.132-0.191])$ increase in the likelihood of voting for the incumbents. From a different angle, if a voter would move from being extremely pessimistic to extremely optimistic about the national economy, the probability to vote for the coalition government would increase by 0.467 , $95 \% \mathrm{Cls}[0.354-0.581] .{ }^{12}$ Of course, this effect is not entirely precise as the model does not include the treatments and neglects any demographic heterogeneity in the sample. ${ }^{13}$

The conditional effect of economic prospects on vote intention for different treatments will determine whether and how room to maneuver and economic voting interact. The following equation represents the empirical specification to be used in the main statistical model:

$$
Y_{i}=\alpha+\tau_{i} \beta_{1-2}+\gamma_{i} \beta_{3}+\tau_{i} \times \gamma_{i} \beta_{4-5}+\eta_{i} \beta_{6-k}+\epsilon
$$

In equation (1) $i$ indexes survey respondents and $Y_{i}$ is the probability of voting for each of the

\footnotetext{
${ }^{12}$ The standard errors are calculated using the delta method. The calculations are based on a model with no controls. When the control variables are included and set to their mean values the results do not change substantially. The 0.167 probability corresponds to an approximate 0.09 marginal effect.

${ }^{13}$ The actual logit coefficients can be found in Table A.3 and the predicted probabilities for all possible scenarios are displayed in Table A.4 in the Online Appendix.
} 
competing parties. On the right-hand side, $\alpha$ is a constant and $\tau_{i}$ is the treatment variable that takes the values of 0 for control, 1 for Full Room and 2 for No room. $\gamma_{i}$ represents the economic prospections for each respondent and $\tau_{i} \times \gamma_{i}$ is the interaction effect. The $\eta_{i}$ term is a vector of covariates to be used as controls in some of the models. Finally, $\epsilon$ is random error. Note also that the estimated coefficients for $\tau$ and the interaction term represent the two treatment variables compared to the control group. The results from the estimation of Eq. (1) are reported in Table 3 where the estimator is now a multinomial logit and the coefficients are contrasted between voting for the incumbent coalition or voting for any of the opposition parties and being undecided serving as the reference category for both outcomes.

-Table 3 around here-

Table 3 displays entries from three models. The first two columns (1) and (2) correspond to a model that estimates the conditional relationships without any controls. Column (1) corresponds to a vote for the incumbent coalition parties (PASOK and New Democracy) whereas the coefficients from column (2) represent support for the opposition parties. The only significant predictor in this equation is the Economic Prospects variable and suggests that a more positive economic outlook brings about an increase in the probability of voting for the incumbent $\left(\beta_{\text {Coal }}=0.99, p \simeq 0.00\right)$ and a decrease in the likelihood of voting for the opposition parties $\left(\beta_{O p p}=-0.17, p<0.10\right)$. Since this is a multiplicative equation the above coefficients measure economic voting when both $\tau_{1}$ and $\tau_{2}$ equal to 0 or, alternatively, this represents economic voting for the control group.

-Figure 3 around here-

The point estimate for the control group is very close to the uniform economic voting effect discussed above. To establish whether there are differences across the two treatments $\left(\tau_{1}\right.$ and $\left.\tau_{2}\right)$ 
I plotted the marginal effect which can be found on Figure 2. As it was discussed in the literature review, the key theoretical expectation is that economic voting would be lower under constraints and No Room to Maneuver (that is $\tau_{2}$ ) and thus different from the Control Group. Reversely, we should expect higher economic voting under $\tau_{1}$ when the incumbent government is projected to have a Full Room to Maneuver. The marginal effects graphed in Figure 2 clearly show that the economic vote is strong and significant for the control and the two treatment groups. However, there is no substantive conditional effect. In other words, the Room to Maneuver does not condition economic voting and the differences in the marginal effects across treatments and the control group are always around $0 .{ }^{14}$

The second model (Columns (3) and (4)) adds demographic controls whereas the third one (Columns (5) and (6)) also accounts for ideology. Since the study did not measure ideological proximities on a set of policy preferences, attitudes towards Greece's participation in the European Union where used instead. This measure runs from positive to negative and corresponds to the most important cleavage in modern Greek politics and plausibly captures variation in attitudes toward the bailout-agreement. This is a pre-treatment item and does not influence the size of the economic voting coefficients. The corresponding figures of the conditional effects including covariates used as controls can be found in the Online Appendix, Figure A.3.

\section{Optimists vs Pessimists}

The models presented in the previous section make two important assumptions. First they assume linear effects and, secondly, they compare incumbents with opposition parties without actually contrasting between different political parties. The following sets of models uses the main opposition party (SYRIZA) as the dependent variable and the coefficients contrast support for this party compared to each of the coalition partners and an Other category that includes the

\footnotetext{
${ }^{14}$ These differences are based on contrasts of the coefficients using a $\chi^{2}$ statistic. The $95 \%$ confidence intervals always include zero. With demographic controls, the differences in the point estimates are even small smaller.
} 
remaining opposition parties and the undecideds. ${ }^{15}$ Also, rather than looking at the linear effect of economic prospects, the models use the collapsed version of this variable and contrast Optimists and Pessimists. Table 4, which reports the results from these models, shows an alternative coding scheme for the dependent variable. The abstainers are excluded from the analyses and the undecideds are included in the Other category.

-Table 4 around here-

The results are very similar to those reported in Table 3. ${ }^{16}$ The conditional effects are directly visualized in Figure 3. Again, the economic vote does not vary across the control group and the Room to Maneuver treatments. The plotted point estimates along with the respective $95 \%$ confidence intervals show that 1 ) there is no substantive difference between the two treatment groups and 2) in all instances the economic effects on the vote are not smaller compared to the control group.

-Figure 4 around here-

\section{The Room to Maneuver and Political Choices}

Although, economic voting is not affected by maneuverability, this does not mean that politicians do not shirk their responsibilities and that perceptions of responsibility do not have electoral consequences. Voters tend to treat perceptions of responsibility as an important part of their voting calculations. If they think that externally imposed policies are bad (for democracy, themselves or even the economy itself), then they tend to place voting weights on this consideration. In effect,

\footnotetext{
${ }^{15}$ (New Democracy/SYRIZA, PASOK/SYRIZA, Other/SYRIZA)

${ }^{16} \mathrm{In}$ fact, the results are robust to all available combinations of coding the explanatory variables and the coding of the outcome.
} 
it is very likely to observe the following artefact: when perceptions of responsibility are interacted with economic evaluations in observational studies, then the impact of the economy seems to deteriorate as a function of higher values in the responsibility variables. It is thus perceptions of responsibility that have direct effects on the vote and, as a result, the impact of the economy deteriorates. ${ }^{17}$

-Table 5 around here-

Table 5 shows the impact of the manipulated variable on the vote for the coalition government. The results suggest that maneuverability as an experimental manipulation clearly affects the probability of supporting the coalition government and the results are robust when economic considerations are included in the specification. The probability of supporting the coalition government is around $3 \%\left(\beta_{\text {FullRoom }}=0.496\right)$ higher for those getting the treatment of high maneuverability and the effect remains the same when economic evaluations are included in the specification. As suggested by the conditional effects in Tables 3 and 4, the effect of the economy is not susceptible to change in response to group membership. This finding carries out serious implications for other studies that examine interdependence and underpin the political effects on the basis of the Room to Maneuver.

\section{Voter Rationalization and Economic Perceptions}

The results reported in the previous sections clearly show that although international constraints affect the distribution of responsibility for elected and non-elected actors, they do not influence the size of the economic vote. However, there are some caveats inherent in all individual studies

\footnotetext{
${ }^{17}$ Note that when the manipulation check (i.e. the observational equivalent of the treatment) is interacted with economic evaluations, the size of the economic vote is higher for respondents who consider the IMF to be responsible for economic outcomes (see Figure A.4). Clearly, one should not place too much emphasis on this, as the key constitutive part of the relationship is measured post treatment.
} 
of economic voting. Citizens tend to form their economic expectations (less) and retrospective evaluations (more) on the basis of their partisan attachments (Anderson, Mendes and Tverdova, 2004; Evans and Andersen, 2006; Wilcox and Wlezien, 1993). In other words, supporters of the incumbent party tend to exaggerate the health of the economy and opposition supporters tend to undermine it. The empirical consequence of these biases is that regression coefficients tend to be also biased and unreliable.

The economic conditions in Greece were unambiguously severe and it was extremely difficult and risky to experimentally manipulate the state of the economy. The fact that national economic prospections were used instead of retrospections was helpful to negate the problem of motivated reasoning. However, there is also recent research on the topic that shows why this is less of a problem in our case. According to Chzhen, Evans and Pickup (2014), economic perceptions influence party preferences endogenously only when the economy follows a typical pattern. In times of crisis, the economic signal is unambiguous and difficult to contest; partisan attachments become less strong and the economy plays a robust role in political decisions. Their results clearly confirm this plausible pattern.

-Figure 4 around here-

Indeed, partisan attachments in Greece have substantially declined after the IMF loans. However, the survey included questions about past vote in national and European elections. Analyses controlling for voting behavior in the 2014 European election (that took place a month before fieldwork) produces very similar results. Economic prospections matter, but they are not moderated by perceptions of responsibility. Additional analyses of past voting behavior included in the model specification suggest that 1 ) there is no conditional effect and 2) the economic vote remains statistically significant; however, 3) the coefficients are smaller. These results are visualized in the two plots depicted in Figure 4. Clearly, this is a very conservative test of economic voting because past voting behavior is highly correlated with the dependent variable and tends to 
explain most of its variance taking away the predictive power of the remaining covariates. Still, Figure 4 lends extra confidence to the research design and the robustness of the results.

\section{Discussion}

According to an established line of literature, electors in situations where the elected government does not have enough room to design and implement policy are likely to discount the economy from their voting calculations. This paper is motivated by a series of elections that took place during the Great Recession when economic voting increased, party systems transformed and all this under severe external policy impositions. To revisit the theoretical claim purporting the conditional relationship between maneuvering space and economic voting, a survey experiment was designed that showed that external impositions and responsibility over outcomes are important yet more Room to Maneuver does not lead to more economic voting. The experiment was fielded at a crucial point in a fertile setting for experimentation. Greek voters were interviewed just before the $2^{\text {nd }}$ bailout agreement was about to finish making the experimental design both internally and externally valid. The successful manipulation of responsibility over economic policy and the robust economic vote clearly demonstrated that the economy maintains its role as the single most crucial aspect of democratic interactions. But why do we observe this? Why would such an important and plausible parameter as a given government's space to deliver economic policy be irrelevant for economic voting?

One key reason is that the salience of the economic issue is not constant over time (Singer, 2013). During good economic times, issues like crime or corruption become more prevalent in the electors' decision calculi. The economy is still important, but other issues make decision-making harder and obscure a government's competency signal. In bad economic times, like during the Great Recession, economic considerations overshadow everything else and thus the economic vote heightens (Bloom and Price, 1975; Lau, 1982, 1985; Soroka, 2006). This has serious implications 
for the original theory. In good economic times, like those experienced in the last two decades of the 20th century, the salience of the economy as an issue was lower and this coincided with the largest pick in economic interdependence. Globalization, on this account, is not the primary condition for lowering the economic vote. It is just the mere fact that in good times the economic vote is weaker.

Whereas this argument has been contested by many (Duch and Stevenson, 2008; Van der Brug, Van Der Eijk and Franklin, 2008) there is recent empirical evidence on which the globalization/Room to Maneuver argument is also scrutinized. Importantly, these alternative mechanisms show promise and they do a good job in evaluating the robustness of the economic vote in the European periphery. On these accounts, it is not trade openness, capital flows or the Room to Maneuver that attenuate the economic vote but the synchronization of the national business cycles. This synchronization minimizes the deviation between the performances of the international and the local economies (Kayser and Peress, 2016) and thus voters are less likely to use the economy as a yardstick of performance. Voters, in other words, cannot extract a decisive competency signal for the incumbent and thus place less weight on economic considerations. This way of understanding the link of international forces and the economic vote is better equipped to describe its increase in Greece and elsewhere during and after the Great Recession. Compared to most European countries (and the European average) the economic decline was decisively larger and this is why incumbent politicians were condemned to lose elections because of the economy. The experimental results presented in this work are aligned with that view.

The Room to Maneuver at its various manifestations corresponds to the idea that politicians have the ability to shirk responsibility over economic policy and can use the international economic conditions or/and institutions as a scapegoat to displace blame. The eurozone crisis had exactly the same characteristics. Politicians in bailed-out countries where using an institution to avoid the blame for economic austerity and the imposed policy mixture to combat debt. In other words, the Room to Maneuver mechanism was entirely applicable to democracies in the European periphery 
during the Great Recession. A critical -potential- difference between past literature and the Greek case relates to the choice of all the incumbent governments since the first bailout in 2010 to sign and ratify the memoranda. In reality, however, the Greek governments had to choose between a $10-12 \%$ rate from the markets and a much lower borrowing rate. Even if this could ever be considered a choice, the general context is not entirely different from open economies with high FDI and trade openness. It is clear that Greek voters formed strong opinions over the bailouts and their preferences varied along party preference. The same applies to globalized economies, however; economic integration is a policy option and voters respond to it. Centrist voters in open economies are likely to have more positive views over e.g. trade openness, whereas voters of the extreme left or the extreme right might object to it. What matters is that political rhetoric is the same and, on this basis, the context offers leeway to successfully manipulate perceptions of responsibility.

The way voters react to this rhetoric can have serious normative implications. The literature linking government constraints and accountability had portrayed a gloomy picture about the democratic consequences of the weakening economic vote. Indeed, if the defining feature of democracy is the ability voters have to reward for good and punish for bad outcomes, then in the presence of unaccountable policy makers democratic interactions weaken. If political rhetoric is successful and politicians can escape or misplace blame, then such pessimism is warranted. If voters, on the other hand, discount such rhetorical attempts, then accountability (as manifested in the variation of the economic vote) becomes the strong incentivizing mechanism that motivates politicians to pursue better policies and better outcomes. Even when governments are so constrained by supranational institutions, voters will still punish them if the economy is plummeting and reward them when the economy is improving. In fact, when looking at the observational measure of responsibility and when comparing the two poles, less room to maneuver (IMF responsibility) leads to higher economic voting. Middle ground answers, i.e. less clarity of 
responsibility, produce less economic voting (see Figure A.4 in the Appendix). ${ }^{18}$

On a final note, the Room to Maneuver has informed a great deal of research examining international constraints and electoral politics that go beyond the economic vote and touch upon party politics and political representation (Ward, Ezrow and Dorussen, 2011; Ezrow and Hellwig, 2014; Hellwig, 2014, 2015). Without doubt, this is still a very plausible mechanism that could in fact influence how political parties campaign on issues and how they rationalize their decisions when they are in government. On its own, the finding of this paper that responsibility directly affects incumbents' support lends confidence to the previously mentioned work on party competition. Political parties have incentives to consider international constraints (like globalization and participation in supranational structures) when they choose their policy locations before elections. Whether their policy shifts are optimal and popular should be addressed in future research.

\footnotetext{
${ }^{18}$ As mentioned before, this measure is recorded post-outcome and causal inferences should be made with reservation.
} 


\section{References}

Alcañiz, Isabella and Timothy Hellwig. 2011. "Who's to Blame? The Distribution of Responsibility in Developing Democracies." British Journal of Political Science 41(02):389-411.

Alesina, Alberto, John Londregan and Howard Rosenthal. 1993. "A Model of the Political Economy of the United States." The American Political Science Review 87(1):pp. 12-33.

Anderson, Cameron D. 2006. "Economic Voting and Multilevel Governance: A Comparative Individual-Level Analysis." American Journal of Political Science 50(2):449-463.

Anderson, Christopher J. 1995. Blaming the government: Citizens and the economy in five European democracies. ME Sharpe Inc.

Anderson, Christopher J. 2000. "Economic voting and political context: a comparative perspective." Electoral Studies 19(2-3):151-170.

Anderson, Christopher, Silvia Mendes and Yuliya Tverdova. 2004. "Endogenous economic voting: evidence from the 1997 British election." Electoral Studies 23(4):683-708.

Bartels, Larry M. 2011. "Ideology and Retrospection in Electoral Responses to the Great Recession." Unpublished Manuscript.

Bloom, Howard S. and H. Douglas Price. 1975. "Voter Response to Short-Run Economic Conditions: The Asymmetric Effect of Prosperity and Recession." The American Political Science Review 69(4):pp. 1240-1254.

Burgoon, Brian. 2001. "Globalization and Welfare Compensation: Disentangling the Ties that Bind." International Organization 55(3):509-551.

Chzhen, Kat, Geoffrey Evans and Mark Pickup. 2014. "When do Economic Perceptions Matter for Party Approval?" Political Behavior 36(2):291-313. 
Danhong, Zhang. 2014. http://www.dw.de/postponing-greeces-day-of-reckoning/a17893964. Last Accessed: 2015-06-16.

Dreher, Axel and Roland Vaubel. 2004. "The Causes and Consequences of IMF Conditionality." Emerging Markets Finance and Trade 40(3):26-54.

Duch, Raymond M. and Randy Stevenson. 2010. "The Global Economy, Competency, and the Economic Vote." The Journal of Politics 72(01):105-123.

Duch, Raymond and Randolph Stevenson. 2008. The economic vote: How political and economic institutions condition election results. Cambridge University Press.

EU. 2015. "Financial assistance to Greece." http://ec.europa.eu/economy_finance/ assistance_eu_ms/greek_loan_facility/index_en.htm. Accessed: 2015-06-16.

Evans, Geoffrey and Robert Andersen. 2006. "The Political Conditioning of Economic Perceptions." The Journal of Politics 68(1):pp. 194-207.

Ezrow, Lawrence and Timothy Hellwig. 2014. "Responding to Voters or Responding to Markets? Political Parties and Public Opinion in an Era of Globalization." International Studies Quarterly 58(4):816-827.

Fearon, James D. 1999. "Electoral accountability and the control of politicians: selecting good types versus sanctioning poor performance." Democracy, accountability, and representation 55:61.

Fernández-Albertos, José, Alexander Kuo and Laia Balcells. 2013. "Economic Crisis, Globalization, and Partisan Bias: Evidence from Spain." International Studies Quarterly 57(4):804816. 
Fraile, Marta and Michael S. Lewis-Beck. 2014. "Economic vote instability: Endogeneity or restricted variance? Spanish panel evidence from 2008 and 2011." European Journal of Political Research 53(1):160-179.

Garrett, Geoffrey. 1998a. "Global Markets and National Politics: Collision Course or Virtuous Circle?" International Organization 52:787-824.

Garrett, Geoffrey. 1998b. Partisan politics in the global economy. Cambridge University Press.

Garrett, Geoffrey and Deborah Mitchell. 2001. "Globalization, government spending and taxation in the OECD." European Journal of Political Research 39(2):145-177.

Hellwig, Timothy. 2008. "Globalization, Policy Constraints, and Vote Choice." The Journal of Politics 70:1128-1141.

Hellwig, Timothy. 2014. "Balancing Demands: The World Economy and the Composition of Policy Preferences." The Journal of Politics 76:1-14.

Hellwig, Timothy. 2015. Globalization and mass politics: Retaining the room to maneuver. Cambridge University Press.

Hellwig, Timothy and David Samuels. 2007. "Voting in open economies: The electoral consequences of globalization." Comparative Political Studies 40(3):283.

Hellwig, Timothy and Eva Coffey. 2011. "Public opinion, party messages, and responsibility for the financial crisis in Britain." Electoral Studies 30(3):417 - 426. Special Symposium on the Politics of Economic Crisis.

Hellwig, Timothy T. 2001. "Interdependence, Government Constraints, and Economic Voting." Journal of Politics 63(4):1141-1162. 
Hellwig, Timothy T., Eve M. Ringsmuth and John R. Freeman. 2008. "The American Public and the Room to Maneuver: Responsibility Attributions and Policy Efficacy in an Era of Globalization." International Studies Quarterly 52(4):855-880.

Hobolt, Sara Binzer, James Tilley and Jill Wittrock. 2013. "Listening to the Government: How Information Shapes Responsibility Attributions." Political Behavior 35(1):153-174.

Hobolt, Sara Binzer, James Tilley and Susan Banducci. 2013. "Clarity of responsibility: How government cohesion conditions performance voting." European Journal of Political Research 52(2):164-187.

IMF. 2014. "Fifth Review of the Greek Programme." https://www.imf .org/external/pubs/ ft/scr/2014/cr14151.pdf. Accessed: 2015-06-16.

Johns, Robert. 2011. "Credit Where it's Due? Valence Politics, Attributions of Responsibility, and Multi-Level Elections." Political Behavior 33:53-77.

Kayser, Mark A and Michael Peress. 2016. The Buck Stops over There? Benchmarking Elections in the Open Economy. In Globalization and Domestic Politics: Parties, Elections, and Public Opinion, ed. Vowles Jack and Georgios Xezonakis. Oxford: Oxford University Press chapter 5.

Kayser, Mark Andreas and Michael Peress. 2012. "Benchmarking across Borders: Electoral Accountability and the Necessity of Comparison." American Political Science Review 106(03):661-684.

Kentikelenis, Alexander E., Thomas H. Stubbs and Lawrence P. King. forthcoming. "IMF conditionality and development policy space, 1985-2014." Review of International Political Economy 23(4):543-582.

Kontogiannis, Dimitris. 2014. "Time approaching for the IMF to go." http://www. 
ekathimerini.com/4dcgi/_w_articles_wsite2_1_16/02/2014_537433. Last Accessed: 2015-06-16.

Kosmidis, Spyros. 2014. "Government Constraints and Accountability: Economic Voting in Greece Before and During the IMF Intervention." West European Politics 37(5):1136-1155.

Lau, Richard R. 1982. "Negativity in Political Perception." Political Behavior 4(4):pp. 353-377.

Lau, Richard R. 1985. "Two Explanations for Negativity Effects in Political Behavior." American Journal of Political Science 29(1):pp. 119-138.

Lewis-Beck, Michael and Martin Paldam. 2000. "Economic voting: an introduction." Electoral Studies 19:113-121.

Lewis-Beck, Michael S. 1988. Economics and elections: The major Western democracies. Ann Arbor: University of Michigan Press.

Lewis-Beck, Michael S. and Marina Costa-Lobo. 2016. The Economic Vote: Ordinary vs. Extraordinary Times. In Handbook of Electoral Behaviour, ed. Kai Arzheimer, Evans Jocelyn and Michael S. Lewis-Beck. Sage Publications.

Lewis-Beck, Michael S. and Mary Stegmaier. 2000. "Economic Determinants of Electoral Outcomes." Annual Review of Political Science 3(1):183-219.

Lewis-Beck, Michael S. and Mary Stegmaier. 2008. "The Economic Vote in Transitional Democracies." Journal of Elections, Public Opinion and Parties 18(3):303-323.

Lewis-Beck, Michael S. and Mary Stegmaier. 2013. "The VP-function revisited: a survey of the literature on vote and popularity functions after over 40 years." Public Choice 157(3-4):367385. 
Lobo, Marina Costa and Michael S. Lewis-Beck. 2012. "The integration hypothesis: How the European Union shapes economic voting." Electoral Studies 31(3):522 - 528. Special Symposium: Economic Crisis and Elections: The European Periphery.

Magalhães, Pedro C. 2014. "The Elections of the Great Recession in Portugal: Performance Voting under a Blurred Responsibility for the Economy." Journal of Elections, Public Opinion and Parties 24(2):180-202.

Marsh, Michael and Slava Mikhaylov. 2012. "Economic voting in a crisis: The Irish election of 2011." Electoral Studies 31(3):478 - 484. Special Symposium: Economic Crisis and Elections: The European Periphery.

Michelitch, Kristin, Marco Morales, Andrew Owen and Joshua A. Tucker. 2012. "Looking to the future: Prospective economic voting in 2008 Presidential Elections." Electoral Studies $31(4): 838-851$.

Mosley, Layna. 2000. "Room to Move: International Financial Markets and National Welfare States." International Organization 54:737-773.

Mutz, Diana C. 2011. Population-based survey experiments. Princeton University Press.

Nezi, Roula. 2012. "Economic voting under the economic crisis: Evidence from Greece." Electoral Studies 31(3):498 - 505. Special Symposium: Economic Crisis and Elections: The European Periphery.

Powell, G. Bingham, Jr. and Guy D. Whitten. 1993. "A Cross-National Analysis of Economic Voting: Taking Account of the Political Context." American Journal of Political Science 37(2):pp. 391-414.

Rodrik, Dani. 1997. Has globalization gone too far? Wahington DC: The Institute for International Economics. 
Singer, Matthew M. 2013. "The global economic crisis and domestic political agendas." Electoral Studies 32(3):404 - 410. Economics and Elections: Effects Deep and Wide.

Singer, Matthew M. and Ryan E. Carlin. 2013. "Context Counts: The Election Cycle, Development, and the Nature of Economic Voting." The Journal of Politics 75:730-742.

Smith, Helena. 2014. "Greece tells IMF it wants early exit from rescue programme." http://www. theguardian.com/business/2014/oct/12/greece-rescue-packageimf-christine-lagarde. Last Accessed: 2015-06-16.

Soroka, Stuart N. 2006. "Good News and Bad News: Asymmetric Responses to Economic Information." The Journal of Politics 68(2):pp. 372-385.

Teperoglou, Eftichia and Emmanouil Tsatsanis. 2014. "Dealignment, De-legitimation and the Implosion of the Two-Party System in Greece: The Earthquake Election of 6 May 2012." Journal of Elections, Public Opinion \& Parties 24(2):222-242.

Tucker, Joshua Aaron, Peter Lange, Robert H Bates, Ellen Comisso, Peter Hall, Joel Migdal and Helen Milner. 2006. Regional Economic Voting: Russia, Poland, Hungary, Slovakia, and the Czech Republic, 1990-1999. Cambridge: Cambridge University Press.

Van der Brug, Wouter, Cees Van Der Eijk and Mark Franklin. 2008. The economy and the vote: Economic conditions and elections in fifteen countries. Cambridge University Press.

Vaubel, Roland and Thomas D Willett. 1991. The political economy of international organizations: A public choice approach. New York: Westview Press.

Vowles, Jack. 2008. "Does globalization affect public perceptions of Who in power can make a difference? Evidence from 40 countries, 1996-2006." Electoral Studies 27(1):63 - 76.

Vowles, Jack and Georgios Xezonakis. 2016. Globalization and Domestic Politics: Parties, Elections, and Public Opinion. Oxford University Press. 
Ward, Hugh, Lawrence Ezrow and Han Dorussen. 2011. "Globalization, Party Positions, and the Median Voter." World Politics 63:509-547.

Wilcox, Nathaniel and Christopher. Wlezien. 1993. "The contamination of responses to survey items: Economic perceptions and political judgments." Political Analysis 5(1):181. 


\section{Tables \& Figures}

Table 1: Experimental Conditions

\begin{tabular}{|l|l|}
\hline \hline $\begin{array}{l}\text { Experimental } \\
\text { Group }\end{array}$ & Question Wording \\
\hline Control & $\begin{array}{l}\text { What do you think about the future of the national economy? } \\
\text { In the next two to three years the situation will: }\end{array}$ \\
\hline $\begin{array}{l}\text { F: } \\
\text { Full Room } \\
\text { to maneuver }\end{array}$ & $\begin{array}{l}\text { According the bail-out agreement, the IMF will leave Greece } \\
\text { by the end of this year. This will enable the elected government } \\
\text { to design and implement the policies they prefer. What do you } \\
\text { think about the future of the national economy? In the next two } \\
\text { to three years the situation will: }\end{array}$ \\
\hline $\begin{array}{l}\text { No Room } \\
\text { to maneuver }\end{array}$ & $\begin{array}{l}\text { Four years after the bail-out agreement, the elected Greek } \\
\text { government cannot design or implement policy without consent } \\
\text { from the lenders. What do you think about the future of the } \\
\text { national economy? In the next two to three years the situation } \\
\text { will: }\end{array}$ \\
\hline
\end{tabular}


Figure 1: Differences in economic evaluations across treatment by demographic, attitudinal and choice covariates

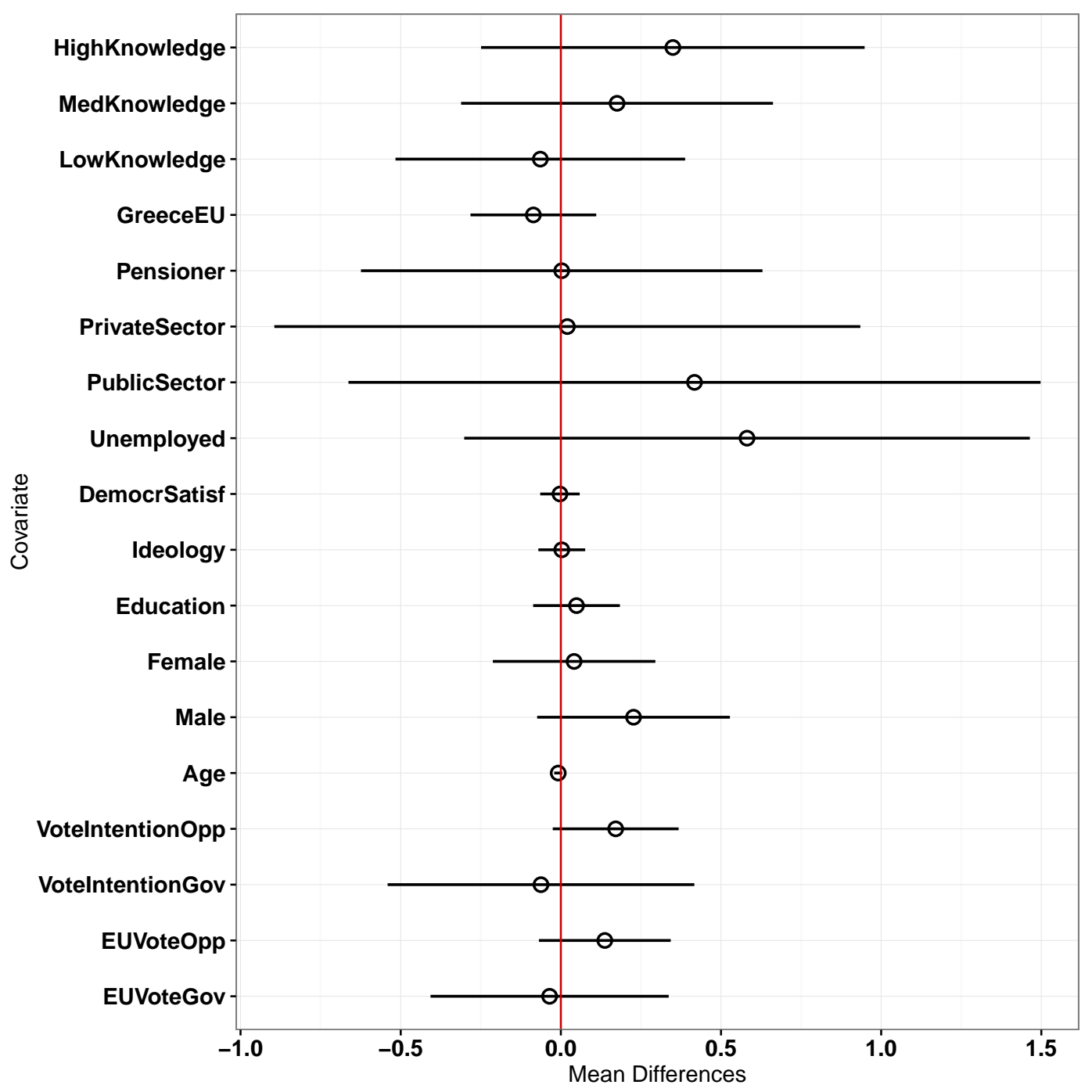

Note: The displayed bars denote $95 \%$ confidence intervals of the difference in economic evaluation across treatment groups for a series of covariates. Ideology and DemocrSatisf and GreeceEU are pre-treatment measures, the demographics are post-treatment, EUVoteGov and EUVoteOpp are vote recall measures from the European Parliament election that took place a month before fieldwork and, finally, VotelntentionGov and VotelntentionOpp are based on the outcome. Intervals based on multiple comparisons are calculated using the Bonferroni adjustment. Mean differences are calculated using separate OLS models predicting economic evaluations (higher values: Optimism) with interaction terms between treatment membership and each of the covariates of interest $\left[\right.$ Econ $=\alpha+\beta_{1-2}$ Treatment $+\beta_{3}$ Covariate $+\beta_{4-k}$ Treatment $\times$ Covariate $\left.+\epsilon\right]$. 
Table 2: Manipulation Check for Room to maneuver Treatment

\begin{tabular}{|c|c|c|}
\hline $\begin{array}{l}\text { National } \\
\text { Responsibility }\end{array}$ & (1) & (2) \\
\hline Full Room & $\begin{array}{c}0.774^{* *} \\
(0.293)\end{array}$ & $\begin{array}{c}0.787 * * \\
(0.296)\end{array}$ \\
\hline No Room & $\begin{array}{c}0.115 \\
(0.287)\end{array}$ & $\begin{array}{c}0.083 \\
(0.288)\end{array}$ \\
\hline Constant & $\begin{array}{l}4.754^{* *} \\
(0.209)\end{array}$ & $\begin{array}{l}7.365 * * \\
(0.863)\end{array}$ \\
\hline Controls & & \\
\hline $\begin{array}{l}\text { Demographics } \\
\text { Pol.Preferences }\end{array}$ & $\begin{array}{l}x \\
x\end{array}$ & $\begin{array}{l}\checkmark \\
\checkmark\end{array}$ \\
\hline $\mathrm{N}$ & 1,023 & 994 \\
\hline
\end{tabular}

Note: Entries are OLS coefficients. The DV measures attribution of responsibility and ranges from 0 (Lenders' Responsibility) to 10 (National Government Responsibility), Controls on the second column include partisan preferences, age, gender, knowledge and education. Standard errors in parentheses $* * \mathrm{p}<0.01, * \mathrm{p}<0.05$ 
Table 3: Multinomial Logit Model of Economic Voting by Experimental Condition

\begin{tabular}{|c|c|c|c|c|c|c|}
\hline & $\begin{array}{c}(1) \\
\text { Coalition }\end{array}$ & $\begin{array}{c}(2) \\
\text { Opposition }\end{array}$ & $\begin{array}{c}(3) \\
\text { Coalition }\end{array}$ & $\begin{array}{c}(4) \\
\text { Opposition }\end{array}$ & $\begin{array}{c}5) \\
\text { Coalition }\end{array}$ & $\begin{array}{c}6) \\
\text { Opposition }\end{array}$ \\
\hline Economic Prospects & $\begin{array}{l}0.990 * * \\
(0.192)\end{array}$ & $\begin{array}{l}-0.168 \\
(0.095)\end{array}$ & $\begin{array}{c}0.988 * * \\
(0.187)\end{array}$ & $\begin{array}{l}-0.155 \\
(0.096)\end{array}$ & $\begin{array}{l}0.893^{* *} \\
(0.201)\end{array}$ & $\begin{array}{l}-0.103 \\
(0.099)\end{array}$ \\
\hline Full Room $\left(\tau_{1}\right)$ & $\begin{array}{l}1.256 \\
(0.995)\end{array}$ & $\begin{array}{c}0.518 \\
(0.366)\end{array}$ & $\begin{array}{c}1.320 \\
(0.963)\end{array}$ & $\begin{array}{c}0.521 \\
(0.371)\end{array}$ & $\begin{array}{c}1.382 \\
(1.041)\end{array}$ & $\begin{array}{c}0.563 \\
(0.377)\end{array}$ \\
\hline No Room $\left(\tau_{2}\right)$ & $\begin{array}{c}1.284 \\
(0.938)\end{array}$ & $\begin{array}{c}0.208 \\
(0.365)\end{array}$ & $\begin{array}{c}1.315 \\
(0.908)\end{array}$ & $\begin{array}{c}0.208 \\
(0.371)\end{array}$ & $\begin{array}{c}1.464 \\
(0.979)\end{array}$ & $\begin{array}{c}0.163 \\
(0.379)\end{array}$ \\
\hline$\tau_{1} \#$ EconomicProspects & $\begin{array}{l}-0.191 \\
(0.256)\end{array}$ & $\begin{array}{l}-0.164 \\
(0.135)\end{array}$ & $\begin{array}{l}-0.235 \\
(0.248)\end{array}$ & $\begin{array}{l}-0.171 \\
(0.136)\end{array}$ & $\begin{array}{l}-0.245 \\
(0.267)\end{array}$ & $\begin{array}{c}-0.186 \\
(0.136)\end{array}$ \\
\hline$\tau_{2} \#$ Economic Prospects & $\begin{array}{l}-0.273 \\
(0.244)\end{array}$ & $\begin{array}{l}-0.106 \\
(0.131)\end{array}$ & $\begin{array}{l}-0.288 \\
(0.236)\end{array}$ & $\begin{array}{l}-0.104 \\
(0.132)\end{array}$ & $\begin{array}{l}-0.319 \\
(0.252)\end{array}$ & $\begin{array}{l}-0.088 \\
(0.133)\end{array}$ \\
\hline Age & & & $\begin{array}{l}0.028^{*} \\
(0.007)\end{array}$ & $\begin{array}{c}0.000 \\
(0.005)\end{array}$ & $\begin{array}{l}0.028^{*} \\
(0.008)\end{array}$ & $\begin{array}{c}0.001 \\
(0.005)\end{array}$ \\
\hline Gender & & & $\begin{array}{c}-0.048 \\
(0.211)\end{array}$ & $\begin{array}{c}-0.250 \\
(0.141)\end{array}$ & $\begin{array}{c}0.030 \\
(0.216)\end{array}$ & $\begin{array}{c}-0.278 \\
(0.144)\end{array}$ \\
\hline Education & & & $\begin{array}{l}-0.068 \\
(0.075)\end{array}$ & $\begin{array}{c}-0.116^{* *} \\
(0.050)\end{array}$ & $\begin{array}{l}-0.110 \\
(0.076)\end{array}$ & $\begin{array}{c}-0.123^{* *} \\
(0.051)\end{array}$ \\
\hline GreeceEU (Negative) & & & & & $\begin{array}{c}-0.589 * * \\
(0.143)\end{array}$ & $\begin{array}{l}0.248 * * \\
(0.084)\end{array}$ \\
\hline Constant & $\begin{array}{c}-4.862 * * \\
(0.755) \\
\end{array}$ & $\begin{array}{c}0.267 \\
(0.267) \\
\end{array}$ & $\begin{array}{c}-5.951^{* *} \\
(0.980) \\
\end{array}$ & $\begin{array}{l}1.064^{* *} \\
(0.504)\end{array}$ & $\begin{array}{c}-4.659 * * \\
(1.034) \\
\end{array}$ & $\begin{array}{c}0.461 \\
(0.561)\end{array}$ \\
\hline $\begin{array}{l}\mathrm{N} \\
R^{2}\end{array}$ & $\begin{array}{c}1,036 \\
0.08\end{array}$ & $\begin{array}{c}1,036 \\
0.08\end{array}$ & $\begin{array}{c}1,035 \\
0.10\end{array}$ & $\begin{array}{c}1,035 \\
0.10\end{array}$ & $\begin{array}{c}1,019 \\
0.11\end{array}$ & $\begin{array}{c}1,019 \\
0.11\end{array}$ \\
\hline
\end{tabular}

Note: Entries are multinomial logit coefficients predicting vote choices for the incumbent coalition and the opposition using undecided as the reference category. Robust standard errors in parentheses $* * \mathrm{p}<0.01, * \mathrm{p}<0.05$ 
Figure 2: Economic Voting by Experimental Condition

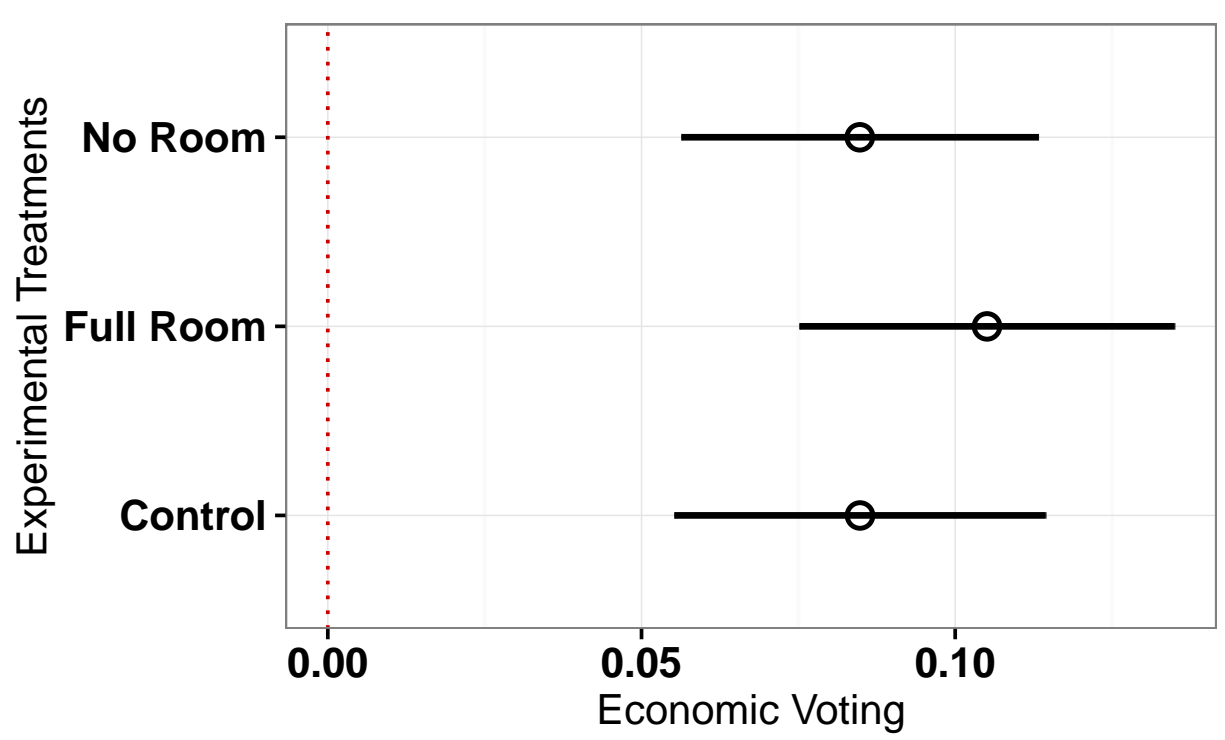

Note: The circle represents the point estimate of the marginal effects and the bars simulate $95 \%$ Confidence Intervals. The plot is based on Column 1 of Table 3 predicting support for the coalition partners without any controls. When controls are included in the specification (see Columns 3 and 5) the results are very similar and can be found in the Online Appendix on Figure A.2 
Table 4: Multinomial Logit with Party Comparisons and a Distinction of Optimists and Pessimists.

\begin{tabular}{|c|c|c|c|c|c|c|}
\hline & $\begin{array}{c}(1) \\
\text { Other }\end{array}$ & $\begin{array}{l}\text { (2) } \\
\text { ND }\end{array}$ & $\begin{array}{c}(3) \\
\text { PASOK }\end{array}$ & $\begin{array}{c}(4) \\
\text { Other }\end{array}$ & $\begin{array}{l}\text { (5) } \\
\text { ND }\end{array}$ & $\begin{array}{c}(6) \\
\text { PASOK }\end{array}$ \\
\hline Economic Pessimists & $\begin{array}{c}-0.089 \\
(0.411)\end{array}$ & $\begin{array}{l}-2.453^{*} \\
(1.180)\end{array}$ & $\begin{array}{c}-1.710 \\
(1.281)\end{array}$ & $\begin{array}{l}-0.042 \\
(0.414)\end{array}$ & $\begin{array}{l}-2.117 \\
(1.188)\end{array}$ & $\begin{array}{c}-1.412 \\
(1.288)\end{array}$ \\
\hline Economic Optimists & $\begin{array}{c}0.679 \\
(0.511)\end{array}$ & $\begin{array}{l}1.657^{*} \\
(0.732)\end{array}$ & $\begin{array}{l}1.440 \\
(0.933)\end{array}$ & $\begin{array}{c}0.663 \\
(0.513)\end{array}$ & $\begin{array}{l}1.476^{*} \\
(0.741)\end{array}$ & $\begin{array}{c}1.083 \\
(0.953)\end{array}$ \\
\hline Full Room $\left(\tau_{1}\right)$ & $\begin{array}{c}0.234 \\
(0.480)\end{array}$ & $\begin{array}{c}0.476 \\
(0.768)\end{array}$ & $\begin{array}{l}-0.135 \\
(1.094)\end{array}$ & $\begin{array}{c}0.232 \\
(0.481)\end{array}$ & $\begin{array}{c}0.445 \\
(0.779)\end{array}$ & $\begin{array}{c}-0.112 \\
(1.099)\end{array}$ \\
\hline No Room $\left(\tau_{2}\right)$ & $\begin{array}{c}0.104 \\
(0.472)\end{array}$ & $\begin{array}{c}0.010 \\
(0.801)\end{array}$ & $\begin{array}{c}-0.225 \\
(1.090)\end{array}$ & $\begin{array}{c}0.104 \\
(0.473)\end{array}$ & $\begin{array}{l}-0.063 \\
(0.811)\end{array}$ & $\begin{array}{c}-0.270 \\
(1.097)\end{array}$ \\
\hline$\tau_{1} \#$ Pessimists & $\begin{array}{l}-0.258 \\
(0.562)\end{array}$ & $\begin{array}{c}1.451 \\
(1.336)\end{array}$ & $\begin{array}{l}-0.101 \\
(1.807)\end{array}$ & $\begin{array}{l}-0.250 \\
(0.564)\end{array}$ & $\begin{array}{c}1.492 \\
(1.347)\end{array}$ & $\begin{array}{c}-0.088 \\
(1.813)\end{array}$ \\
\hline$\tau_{1} \#$ Optimists & $\begin{array}{c}0.099 \\
(0.560)\end{array}$ & $\begin{array}{c}1.057 \\
(1.432)\end{array}$ & $\begin{array}{c}1.599 \\
(1.585)\end{array}$ & $\begin{array}{c}0.113 \\
(0.562)\end{array}$ & $\begin{array}{c}1.274 \\
(1.443)\end{array}$ & $\begin{array}{c}1.762 \\
(1.593)\end{array}$ \\
\hline$\tau_{2} \#$ Pessimists & $\begin{array}{c}0.101 \\
(0.766)\end{array}$ & $\begin{array}{c}0.286 \\
(1.007)\end{array}$ & $\begin{array}{c}0.664 \\
(1.340)\end{array}$ & $\begin{array}{c}0.112 \\
(0.767)\end{array}$ & $\begin{array}{c}0.298 \\
(1.019)\end{array}$ & $\begin{array}{c}0.849 \\
(1.356)\end{array}$ \\
\hline$\tau_{2} \#$ Optimists & $\begin{array}{c}-0.192 \\
(0.689)\end{array}$ & $\begin{array}{c}0.263 \\
(0.980)\end{array}$ & $\begin{array}{c}0.112 \\
(1.297)\end{array}$ & $\begin{array}{l}-0.198 \\
(0.690)\end{array}$ & $\begin{array}{c}0.291 \\
(0.991)\end{array}$ & $\begin{array}{c}0.319 \\
(1.314)\end{array}$ \\
\hline GreeceEU (Negative) & & & & $\begin{array}{l}-0.129 \\
(0.112)\end{array}$ & $\begin{array}{c}-0.861^{* *} \\
(0.190)\end{array}$ & $\begin{array}{c}-0.801^{* *} \\
(0.276)\end{array}$ \\
\hline Constant & $\begin{array}{l}1.394 * \\
(0.672)\end{array}$ & $\begin{array}{c}-3.258^{* *} \\
(1.080)\end{array}$ & $\begin{array}{l}-1.653 \\
(1.395)\end{array}$ & $\begin{array}{l}1.620^{*} \\
(0.712)\end{array}$ & $\begin{array}{c}-1.789 \\
(1.125)\end{array}$ & $\begin{array}{l}-0.196 \\
(1.465)\end{array}$ \\
\hline $\mathrm{N}$ & 1,035 & 1,035 & 1,035 & 1,019 & 1,019 & 1,019 \\
\hline Pseudo $-R^{2}$ & 0.095 & 0.095 & 0.095 & 0.11 & 0.11 & 0.11 \\
\hline
\end{tabular}

Note: 1. Baseline Comparison: SYRIZA: Radical Left Part (Main Opposition), 2. PASOK: Panhellenic Socialist Movement,ND: New Democracy, Other: All Other Parties, 3. Robust Standard errors in parentheses, 4. ${ }^{* *} \mathrm{p}<0.01,{ }^{*} \mathrm{p}<0.05$, Controls as in Table 3 
Figure 3: Economic Voting for Optimists and Pessimists by Experimental Condition

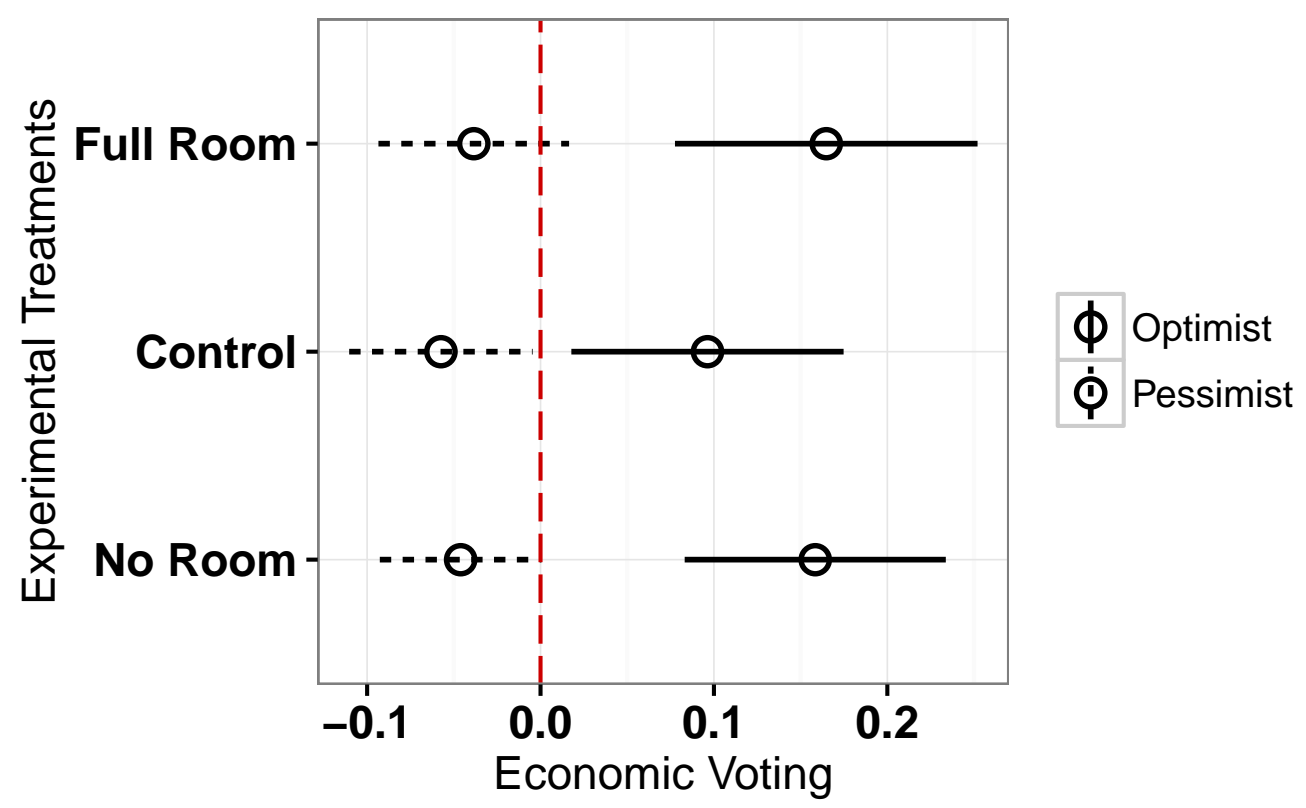

Note: The empty circles represent point estimates of the marginal effects for optimistic voters and the black circles the corresponding effects for pessimists. The bars show 95\% Confidence Intervals. The plot is based on Table 4

Figure 4: Economic Voting by Experimental Condition Controlling for Past Vote Choice

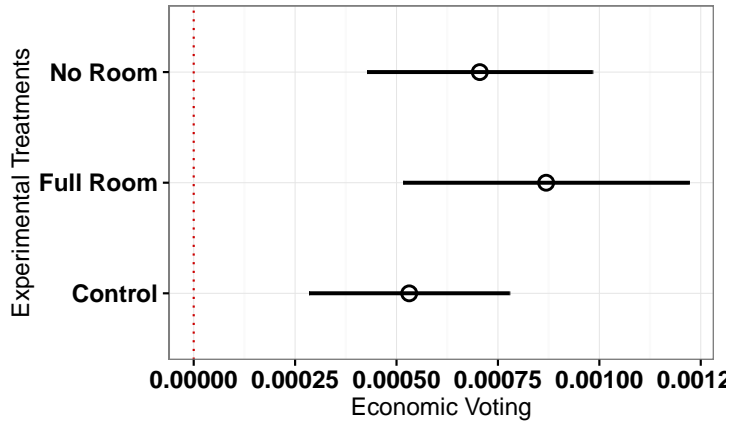

(a) National Election Party Choice

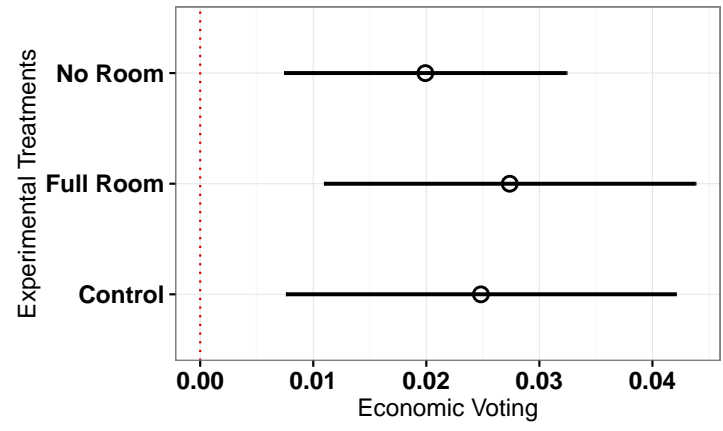

(b) EU Election Party Choice 
Table 5: Multinomial Logit predicting the vote from maneuverability and economic evaluations

\begin{tabular}{lcccc}
\hline \hline & $(1)$ & $(2)$ & $(3)$ & $(4)$ \\
& Coalition & Opposition & Coalition & Opposition \\
\hline \multirow{2}{*}{ Full Room $\tau_{1}$} & $0.491^{* *}$ & 0.164 & 0.506 & 0.100 \\
& $(0.249)$ & $(0.165)$ & $(0.267)$ & $(0.172)$ \\
No Room $\tau_{2}$ & 0.317 & -0.031 & 0.252 & -0.054 \\
& $(0.247)$ & $(0.161)$ & $(0.262)$ & $(0.168)$ \\
Pessimists & & & $-0.923^{* *}$ & 0.324 \\
& & & $(0.342)$ & $(0.171)$ \\
Optimists & & & $1.075^{* *}$ & $-0.483^{*}$ \\
& & & $(0.272)$ & $(0.198)$ \\
Constant & $-3.124 * *$ & 0.799 & $-3.094^{* *}$ & 0.645 \\
& $(0.689)$ & $(0.426)$ & $(0.718)$ & $(0.453)$ \\
& & & & \\
$\mathrm{N}$ & 1,071 & 1,071 & 1,035 & 1,035 \\
$R^{2}$ & 0.022 & 0.022 & 0.085 & 0.085 \\
\hline \hline
\end{tabular}

Note: Entries are multinomial logit coefficients predicting vote for the incumbent coalition and the opposition parties. Robust Standard errors in parentheses, $* * \mathrm{p}<0.01, * \mathrm{p}<0.05$ 


\section{Online Appendix}

\section{\#Survey Information}

- Sample: 1,045 Greeks over 18 sampled via a multistage quote random sample.

- Fieldwork: June 16-18, 2014

- Method of Data Collection: CATI (Computer Assisted Telephone Surveys)

- Response Rate: 5025 calls made, 1045 interviews completed (21\%)

\section{\#Survey Items Appearing in Figure 1}

- Knowledge: Additive index of correctly answered knowledge questions that are split into High, Medium and Low groups

- GreeceEU: "Do you think that our membership in the EU so far has had Positive Neutral, or Negative consequences for Greece?"

- DemoSat: "How satisfied are you with the way democracy is working in Greece?" Very Satisfied, Satisfied, Neutral, Dissatisfied, Very Dissatisfied

- L-R Ideology: "On a scale where 0 denotes extreme left and 10 denotes Extreme Right, where would you place yourself?"

- Occupation: Categories Pensioner, Private Sector Employee (PrivateSector), Public Sector Employee ( PublicSector), Unemployed

- Education: Interval scale (6-point) ranging from primary school through to postgraduate studies 


\section{\#Randomization Checks}

Although the advice in the literature is that randomization checks are not necessary when you randomize properly (Mutz, 2011). It is clear, nevertheless, that participation in one group does not systematically vary with none of our chosen demographic and political characteristics. Age, gender and education are selected to represent demographic variables and political ideology is chosen to cover political attitudes. The results from the randomization checks can be found in the following table:

Table A.1: Randomization Check for Room to Maneuver Treatments

\begin{tabular}{lcc}
\hline \hline & $\left(\tau_{1}\right)$ & $\left(\tau_{2}\right)$ \\
\hline \multirow{2}{*}{ AgeCategory 35-54 (Base=18-34) } & 0.365 & -0.011 \\
& $(0.247)$ & $(0.229)$ \\
AgeCategory 55-65+(Base=18-34) & 0.398 & 0.013 \\
& $(0.257)$ & $(0.242)$ \\
Female & $-0.534^{* *}$ & -0.174 \\
& $(0.174)$ & $(0.173)$ \\
Education2 & 0.345 & -0.014 \\
& $(0.462)$ & $(0.450)$ \\
Education3 & 0.451 & -0.023 \\
& $(0.325)$ & $(0.305)$ \\
Education4 & 0.359 & 0.275 \\
& $(0.385)$ & $(0.356)$ \\
Education5 & 0.315 & -0.196 \\
& $(0.327)$ & $(0.308)$ \\
Education6 (High) & 0.019 & 0.259 \\
& $(0.433)$ & $(0.385)$ \\
Ideology & 0.029 & -0.002 \\
& $(0.031)$ & $(0.030)$ \\
Constant & -0.424 & 0.242 \\
& $(0.414)$ & $(0.387)$ \\
& \multicolumn{2}{c}{907} \\
\hline $\mathrm{N}$ & \multicolumn{2}{c}{25.70} \\
$\chi^{2}$ & 0.0129 \\
\hline \hline
\end{tabular}

Note: Entries are multinomial logit coefficients with standard errors in parentheses. Primary School serves as the reference group for education. The base outcome is the control group, $* * p<0.01, * p<0.05$ 


\section{\#Additional Models}

Table A.2 reports the coefficients and time series tests on which Figure A.1 is based on. The series does not exhibit autocorrelation (at various lags) and both $\Delta_{\text {Popularity }}$ and $\Delta_{\text {Sentiment }}$ are stationary processes. The ${ }^{* *}$ in the Dickey Fuller z-test denote significance based on Mackinnon p-values. Figure A.2, just below, examines the same question of post bailout differential economic voting using a rolling regression model.

Table A.2: Time Series Regression of Monthly Changes in Government Popularity, 2005-2015

\begin{tabular}{lc}
\hline \hline & $\Delta$ Popularity \\
\hline \hline & \\
$\Delta$ Sentiment & 0.081 \\
PostBailout & $(0.081)$ \\
& -0.388 \\
PostBailout $\times \Delta_{\text {Sentiment }}$ & $(0.800)$ \\
& $0.296^{* *}$ \\
Honeymoon & $(0.103)$ \\
& $3.206^{* *}$ \\
Constant & $(0.973)$ \\
& -0.694 \\
$\mathrm{~N}$ & $(0.798)$ \\
\hline Breusch-Godfrey LM & 128 \\
Dickey-Fuller $\left(\Delta_{\text {Popularity }}\right) z(t)$ & $-10.69^{* *}$ \\
Dickey-Fuller $\left(\Delta_{\text {Sentiment }}\right) z(t)$ & $-11.00^{* *}$ \\
$R^{2}$ & 0.360 \\
\hline \hline
\end{tabular}

Robust Standard errors in parentheses.

** $\mathrm{p}<0.01,{ }^{*} \mathrm{p}<0.05$ 
Figure A.1: Economic Voting Before and After the First Bailout (05/2010)

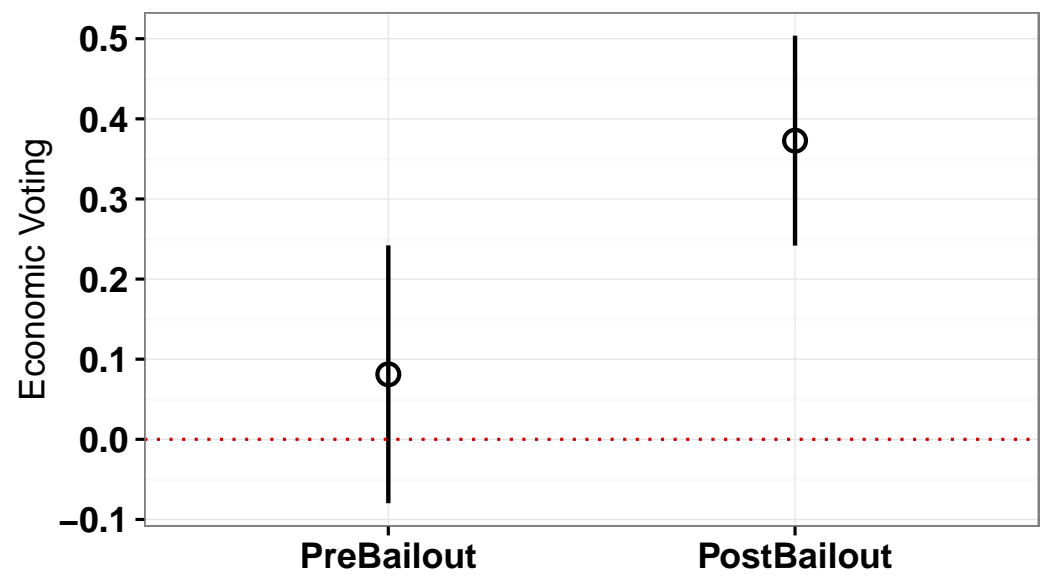

Note: Based on a model with the following specification: $\Delta_{\text {Popularity }}=\alpha+\beta_{1} \Delta_{\text {Sentiment }}+\beta_{2}$ PostBailout + $\beta_{3} \Delta_{\text {Sentiment }} \times$ PostBailout $+\beta_{4-k}$ Controls $+\epsilon$. The full results along with tests for residual autocorrelation and integration can be found in Table A.2 in the appendix. The data was collected from the official websites of polling companies such as Metron Analysis, VPRC, Public Issue and MRB. Data on consumer sentiment was collected from EuroStat.

Figure A.2: Economic Voting Rolling Coefficient (2007-2015), Monthly $\Delta$ Economic Sentiment on $\Delta$ Party Support

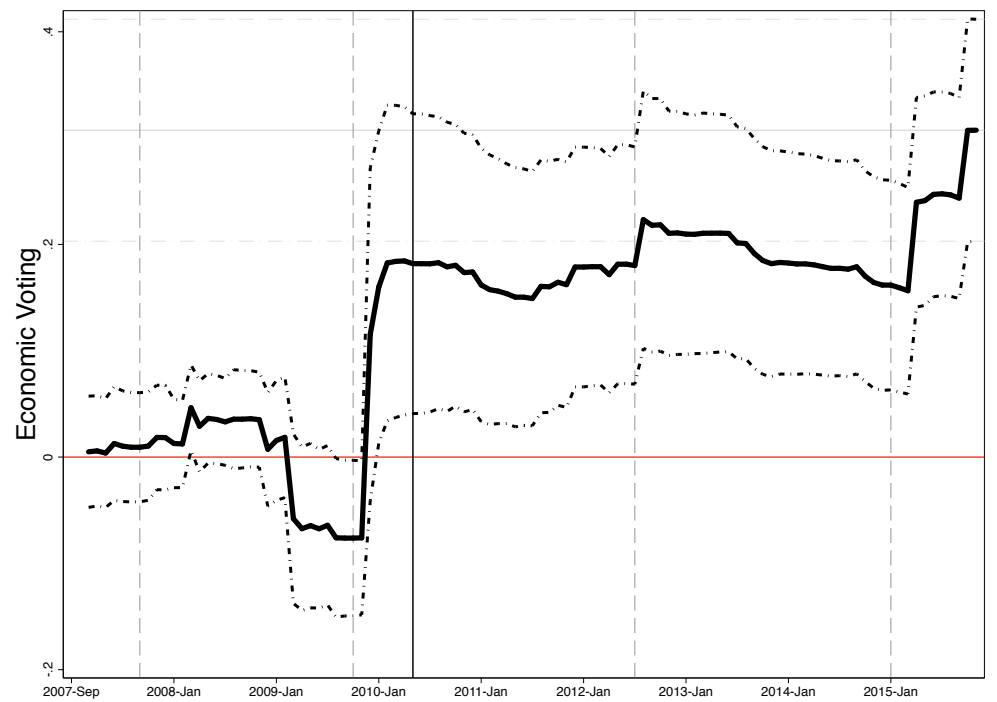

Note: The solid line represents the rolling point estimate of economic voting (i.e. economic sentiment on the incumbent party support) while the dashed lines show the $95 \%$ Confidence Intervals. When these include a 0 value, we can infer that economic voting is not statistically significant. 
Table A.3: Uniform Economic Effects on the Vote: Binary Logit Model Specification

\begin{tabular}{lc}
\hline \hline & Coalition Vote \\
\hline Prospects & $0.915^{* *}$ \\
& $(0.094)$ \\
Constant & $-4.790^{* *}$ \\
& $(0.354)$ \\
\hline & 1,036 \\
$\mathrm{~N}$ & \\
\hline \hline Robust Standard errors in parentheses \\
& $* * \mathrm{p}<0.01,{ }^{*} \mathrm{p}<0.05$
\end{tabular}

Table A.4: Marginal Effects and Predicted Probabilities for Uniform Economic Voting

\begin{tabular}{lccc}
\hline \hline & $\Delta_{P r}$ & Lower95\% & Upper95\% \\
\hline+1 & 0.115 & 0.093 & 0.136 \\
+ SD & 0.162 & 0.132 & 0.191 \\
\hline & & & \\
\hline Pess vs HighPess & 0.053 & 0.010 & 0.095 \\
Neutral vs HighPess & 0.078 & 0.037 & 0.120 \\
Opt vs HighPess & 0.214 & 0.161 & 0.268 \\
HighOpt vs HighPess & 0.467 & 0.354 & 0.581 \\
Neutral vs Pess & 0.025 & -0.030 & 0.081 \\
Opt vs Pess & 0.161 & 0.097 & 0.226 \\
HighOpt vs Pess & 0.415 & 0.295 & 0.534 \\
Opt vs Neutral & 0.136 & 0.072 & 0.200 \\
HighOpt vs Neutral & 0.389 & 0.270 & 0.508 \\
HighOpt vs Opt & 0.253 & 0.130 & 0.377 \\
\hline Average Marginal Effect & 0.092 & 0.075 & 0.109 \\
\hline \hline
\end{tabular}

Note: Given the 5 available responses the predicted probabilities for a a unit increase, a standard deviation increase and inter response differences re calculated using $\frac{1}{1+\exp ^{-\phi}}$ where $\phi$ corresponds to the function used each time for the calculations. 
Figure A.3: Economic Voting Under different Specifications of Table 3

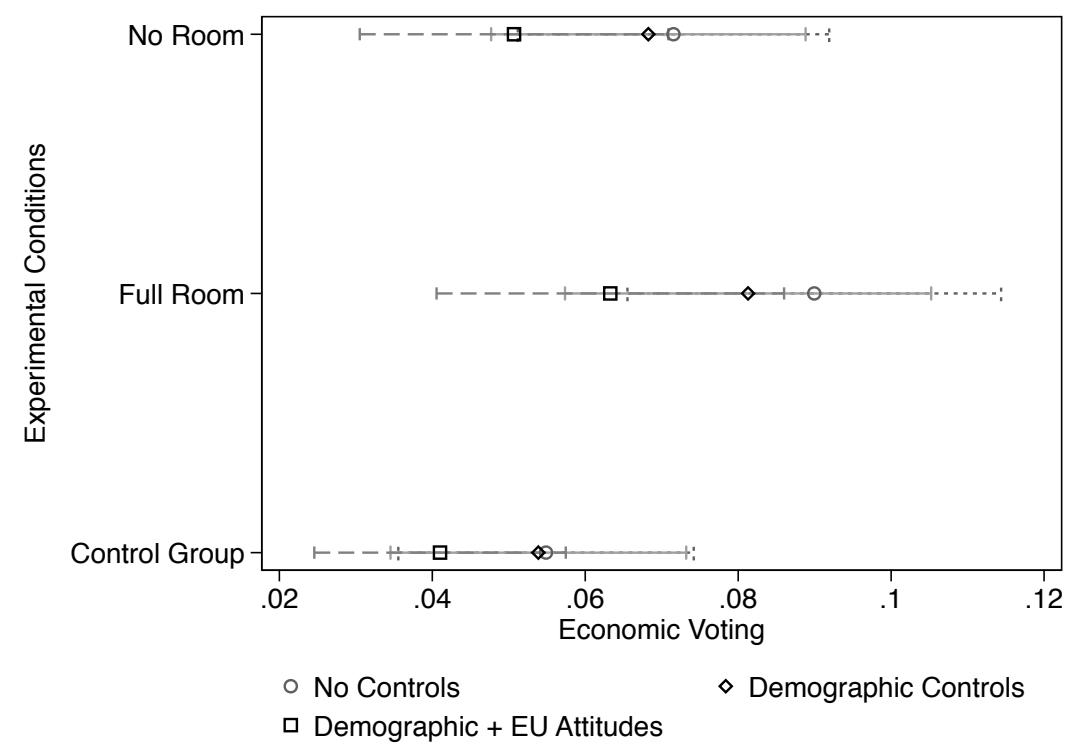

Note: The figure above replicates the main table for alternative model specifications. Each conditional effect corresponds to different specifications.

Figure A.4: Economic voting at different levels of (observational) attributions of responsibility

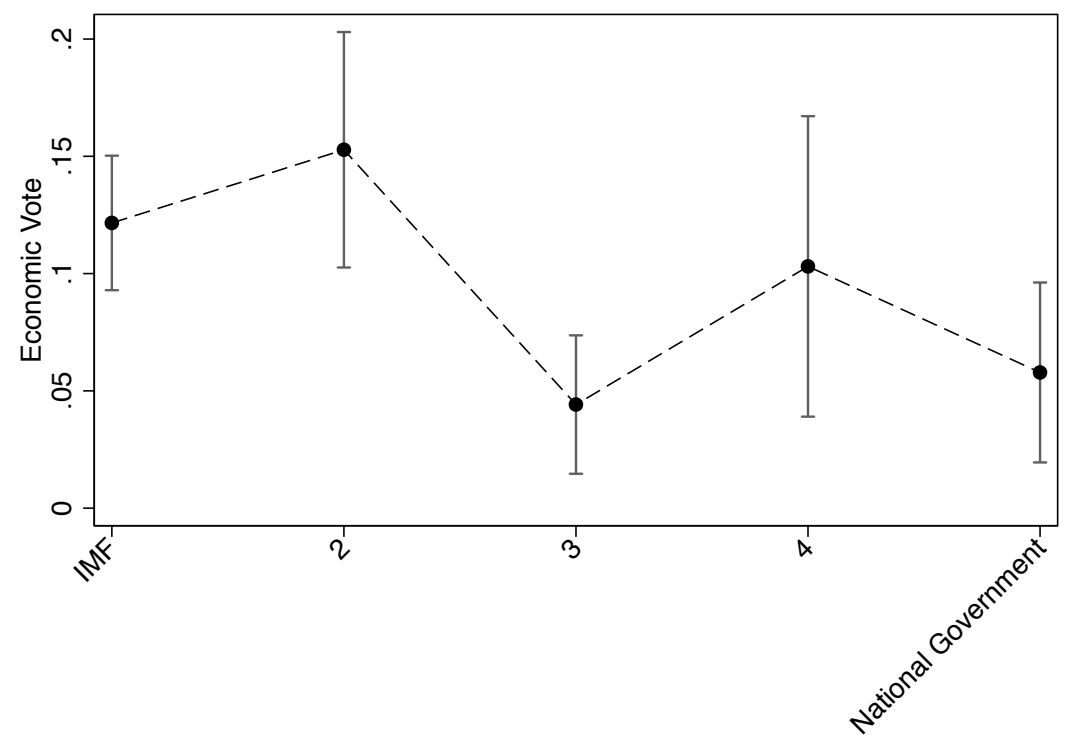

Note: The X-Axis corresponds to different views about who is responsible about who will be responsible for economic policy in the coming years. The circles and the accompanying $95 \%$ confidence bars show the varying levels of economic voting at different values of the responsibility variable. 
\#Political Parties in Greece

Table A.5: Political Parties in Greece

\begin{tabular}{|c|c|c|c|c|c|c|}
\hline Party & Abbr. & Ideology & $\begin{array}{c}\text { Executive Role } \\
\text { During Fieldwork }\end{array}$ & 2009 & 2012 & 2015 \\
\hline New Democracy & (ND) & Center Right & $\begin{array}{l}\text { Prime Minister's } \\
\text { Party }\end{array}$ & $32 \%$ & $28 \%$ & $28 \%$ \\
\hline $\begin{array}{l}\text { Panhellenic } \\
\text { Socialist Movement }\end{array}$ & (PASOK) & Center Left & $\begin{array}{l}\text { Deputy Prime } \\
\text { Minister's Party }\end{array}$ & $44 \%$ & $12 \%$ & $4 \%$ \\
\hline $\begin{array}{l}\text { Coalition of the } \\
\text { Radical Left }\end{array}$ & (SYRIZA) & Left & $\begin{array}{c}\text { Main Opposition } \\
\text { Party }\end{array}$ & $4 \%$ & $27 \%$ & $35 \%$ \\
\hline
\end{tabular}

